\title{
Comments
}

\author{
USURY AND REAL ESTATE INVESTMENT TRUSTS: \\ AN ANALYSIS OF TREASURY REGULATION \\ $1.856(c)(2)($ ii)
}

Treasury Regulation 1.856(c)(2)(ii) provides for the exclusion of usurious interest in calculating the qualified income of a Real Estate Investment Trust (REIT). ${ }^{1}$ This Comment examines the merit of a recent request by the National Association of Real Estate Investment Funds that the Treasury Department withdraw the Regulation. ${ }^{2}$ Part I considers how a Real Estate Investment Trust operates and how the regulation affects its transactions. Part II analyzes whether the regulation effectively discourages REIT's from making loans bearing usurious rates of interest. Part III discusses the difficulty of applying the regulation in light of conflicting state usury laws. Part IV suggests an alternative regulation that both implements the policy considerations underlying the original regulation and promotes certainty and consistency in its administration.

I

\section{OPERATION OF REIT'S}

In 1960 Congress added sections 856-58 to the Internal Revenue Code to provide advantageous tax treatment to widely held trusts or-

1. The tax advantage of organizing as an REIT - the ability to pass income through to shareholders without a tax at the corporate level-does not accrue unless 90 percent of the trust's income is "qualified." INT. REv. CODE of 1954, $\$ 856$ (c)(2) [heremafter cited as CODE]. The specific requirements that determine whether income is qualified are discussed in text accompanying notes 11-26 infra.

2. Letter from National Association of Real Estate Investment Funds (NAREIF) to Internal Revenue Service, Mar. 3, 1971, on file with the California Law Review. The regulation reads as follows:

In computing the percentage requirements in section $856(\mathrm{c})(2)(\mathrm{B})$ and (3)

(B) there shall be included as interest only the amount which constitutes lawful interest for the loan or forbearance of money. Thus, for example, usurious or illegal interest, or fees imposed upon borrowers which are in fact a charge for services in addition to the charge for the use of borrowed money, shall not be imcluded as interest . . . .

Treas. Reg. $\$ 1.856-2(\mathrm{c})(2)$ (ii) (1962). It slould be noted that this regulation lacks statutory basis. The REIT code sections make no mention of usurious interest, and neither does any other code section or regulation provide for this treatment of usurious interest. However, in 1958 the IRS took the position that usurious interest 
ganized for investment in real estate. ${ }^{3}$ These trusts are commonly termed Massachusetts Trusts or Real Estate Investment Trusts. ${ }^{4}$ The legislation permits a qualified REIT, otherwise taxable as a corporation, to serve as a tax-free conduit for its earnings. Distributed earnings are taxed to the shareholders as dividends, and the REIT is taxed only on retained earnings. ${ }^{5}$ One purpose of the legislation was to equalize the tax treatment of REIT's and Regulated Investment Companies (mutual funds), ${ }^{6}$ since both employ pooling arrangements whereby small investors can secure advantages normally available only to those with greater resources. A second purpose was to stimulate the flow of capital into construction and financing of homes, apartments, office buildings, factories, and hotels. ${ }^{7}$

Some meinbers of Congress were concerned, however, that, by assuming the form of an REIT, active real estate companies would secure benefits intended to apply only to the passive trusts. ${ }^{8}$ To satisfy this concern, both the legislation and the implementing regulations set forth strict requirements for an REIT's structure, the nature of its assets, and its sources of income. Failure to meet any of these requirements subjects the trust to taxation as a corporation; that is, distributed

would not be exempt from the personal holding company income of finance companies for purposes of section 542(c)(9). Rev. Rul. 58-357, 1958 Cum. Bull. 353. There have been no other rulings on the treatment of usurious interest.

3. The REIT legislation was attached as an amendment to H.R. 10960, a cigar tax bill. Although President Eisenhower had vetoed an earlier REIT bill in 1956, he signed the present law on September 14, 1960. See generally Kahn, Taxation of Real Estate Investment Trusts, 48 VA. L. REv. 1011 (1962).

4. The Massachusetts Trust is a product of 19th-century Massachusetts law, which disallowed corporate ownership of real estate. To avoid this prohibition the trusts were created as an intermediary form of ownership, and the beneficial shares were sold to the public. The form continued into the early part of this century because the trusts enjoyed favorable tax treatment, being treated as trusts for income tax purposes even though they were essentially corporations. See J. McCoy, H. OLsEN, C. Reed, R. Sandison \& R. Wright, Federal Taxes Affecting Real Estate 276 (3d ed. 1970). In 1935, the Supreme Court held that the trusts should bo taxcd as corporations. Morrissey v. Commissioner, 296 U.S. 344 (1935). Congress responded almost iminediately with favorable legislation for mutual funds [INT. REv. CODE of 1939, §§ 361-62], but it waited until 1960 to enact similar legislation benefiting real estate trusts. See note 3 supra.

5. CODE $\$ 857(\mathrm{~b})(2)$.

6. H.R. REP. No. 2020, 86th Cong., $2 d$ Sess. 4 (1960). However, the analogy to a mutual fund is only superficially correct. In fact, the shareholders in an REIT have an advantage over shareholders in mutual funds, for the dividend paid on a share of corporate stock held by a mutual fund is taxed twice, once at the corporate level and once at the shareholder level. Thus, the exemption given to mutual funds by code sections 851-54 prevents a triple tax. On the other hand, since the REIT's are not subject to tax at the trust level, they are taxed only once, at the shareholder level, and the legislation prevents a double tax. See Kahn, supra note 3, at 1013 n.17.

7. H.R. ReP. No. 2020, 86th Cong., 2d Sess. 4 (1960).

8. Id. 
earnings will be taxed to the REIT as well as to the shareholder. Since the code requires that the trust distribute at least 90 percent of its income, ${ }^{9}$ it will owe tax on income it no longer has, and an adverse determination would force a trust to liquidate substantial assets in order to meet the inultiple tax burden. ${ }^{10}$ These serious consequences necessitate a thorough understanding by the trust and its counsel of the qualification requirements.

The structural requirement for an REIT is five-fold: the trust must be an unincorporated association otherwise taxable as a domestic corporation; $;^{11}$ the REIT must be managed by one or more trustees who hold legal title to the property and control its management; ${ }^{12}$ the trust shares must be owned by at least 100 beneficial owners during at least 335 days of the taxable year; ${ }^{13}$ beneficial ownership of the REIT must be evidenced by transferable shares or certificates;,"14 finally, no more than 50 percent in value of the outstanding shares may be owned by five or fewer persons. ${ }^{15}$ The second requirement is the asset test, which provides that trust assets must consist of at least 75 percent real estate assets, ${ }^{16}$ cash, and government securities on the last day of each fiscal quarter. ${ }^{17}$

The income test is the final requirement and is the most complex and difficult to apply. The principal rule is that a minimum of 75 percent of the trust's gross income must be derived from real property assets; ${ }^{18}$ another 15 percent must be derived either from real property as-

9. The tax advantages are available only if at least 90 percent of the REIT's taxable income is distributed to shareholders. CODE $\$ 857$ (a)(1).

10. Because of this impact, even the threat of an adverse audit report would have a serious effect on the market for the trust shares. In an address to the NAREIF convention in New Orleans on Nov. 12, 1971, the Vice President of NAREIF reported an incident where the threat of an adverse IRS determination as to qualification caused the market value of the trust's shares to drop approximately 50 percent; upon favorable resolution by the IRS, the shares returned to the original level. Address by Durand A. Holladay, Vice President of National Association of Real Estate Investment Funds, Lawyer's Conference: Operational Legal Problems of REITs and their Management Compamies, New Orleans, La., Nov. 12, 1971.

11. CODE $\$ 856(a)(3)$.

12. Id. § 856(a)(1).

13. Id. $\$ 856(\mathrm{a})(5),(\mathrm{b})$.

14. Id. $\S 856(\mathrm{a})(2)$.

15. Id. $\S 856(\mathrm{a})(6)$.

16. Real estate assets are basically mortgages, leasehold or equity interests in real property. Id. $\S 856(\mathrm{c})(6)(\mathrm{B})$. For a discussion of what constitutes real property, see note 22 infra.

17. Id. $\$ 856(\mathrm{c})(5)(\mathrm{A})$. Furthermore, not more than 25 percent of the assets' value may be represented by securities, and those securities nust be highly diversified. The trust inay not own more than 10 percent of the outstanding shares of any one issue, and the shares of a single corporation inay not constitute more than five percent of the total trust assets.

18. Id. $\S 856(\mathrm{c})(3)$. Real property assets are discussed in note 16 supra. 
sets, dividends and interest, or gains from the sale of stock, securities, or real property. ${ }^{10}$ Thus, only 10 percent of the trust's gross income may be derived from unqualified sources.

The 75 percent test requires income to be derived from either real property ${ }^{20}$ or the interest on loans secured by real property. ${ }^{21}$ While this test includes rental income from real property, ${ }^{22}$ such imcome will be excluded if the trust itself manages the properties, ${ }^{23}$ provides noncustomary services to the tenants, ${ }^{24}$ or bases rent directly or indirectly on the net imcome of any person. ${ }^{25}$

The Treasury Department has grafted restrictive ${ }^{20}$ and vague ${ }^{27}$

19. Id. $\S 856(\mathrm{c})(2)$. The statute expresses this test by providing first that 90 percent of the trust's gross income must be derived from real estate assets; gains from the sale of stocks, securities, or real property; dividends; or interest. Id. The statute then provides that 75 percent of the trust's gross incoine must be derived solely from real estate assets. Id. $\$ 856(\mathrm{c})(3)$.

20. Id. $\& 856(\mathrm{c})(3)(\mathrm{A})$.

21. Id. $\$ 856(\mathrm{c})(3)(\mathrm{B})$.

22. The term "real property," however, does not always conform to the traditional concept. It includes, for example, use of defined airspace for condominiums [Rev. Rul. 71-286, 1971 INT. Rev. BuLL. No. 27, at 21] and mobile homes [Rev. Rul. 71-220, 1971 INT. Rev. BULL. No. 19, at 58].

23. CODE \& 856(d)(3).

24. Noncustmoary services include hotel-type services, such as maid service and attended parking lots. Treas. Reg. $\$ 1.856-4$ (b)(3)(i)(B)-(C) (1968). NAREIF has urged the Treasury Department to modify its regulations to permit an REIT to render services that are "common or widespread in connection with the rental of real property." See NAREIF letter, supra note 1, at 13. Examples of serviees that would be permitted under the suggested rules are swimming pools, attended parking garages, storage facilities, and janitorial services for office space.

25. CODE $\$ 856(d)(1)$. The statute does not, however, expressly preclude income based on a tenant's gross receipts, the so-called "pereentage rental," although the regulations take a very restrictive view of this practice. See note 27 infra.

26. For example, where a loan secured by an apartment building is secondarily secured by an interest in the furniture and fixtures, the regulations require an allocation of interest between the real and personal property security, presumably on the basis of fair inarket value. Treas. Reg. $\$ 1.856-2$ (c)(ii) (1960). The pro rata portion allocable to the personal property is nonqualified interest for purposes of the 75 percent test. This provision lias no support in the statute and is an overly mechanical and unrealistic interpretation. It is custoinary for a lender to take an assignment of the appurtenant personal property, but not for the collateral value as such; rather, he wants to ensure that upon foreclosure the owner will not destroy the going-concern value of the project by removing all of the furniture. Furthermore, under the Treasury position even a third-party guarantor would diminish the qualified nature of the loan since the note would be secured other than by real property.

27. For example, code section 856 (d)(1) provides that although rentals cannot be based on the net incoine of any person, any amount received "shall not be excluded . . . solely by reason of being based on a fixed percentage or percentages of receipts or sales." The regulations compound the vagueness of this section by saying that if, considering the lease and all the surrounding circumstances, the rental arrangenent does not conform with normal business practices but is in reality a means 
regulations onto these complex statutes, making interpretation and application of the statutory provisions extremely liazardous. ${ }^{28}$ This is particularly true of the regulation excludimg illegal or usurious interest from qualified incoine. ${ }^{29}$

This regulation failed to attract widespread attention at the time of its promulgation because prevailing interest rates were well below the legal maximums of most states. Recently, lowever, interest rates have approached and exceeded the maximums of many states, and the regulation has become a serious concern to REIT's. ${ }^{30}$ Since REIT's often lend inoney nationwide, a single transaction frequently involves property and residents of more than one state, with a note bearing an interest rate legal in one state but illegal in another. An accurate determination of the applicable usury law is essential for REIT's in order to avoid a threat of disqualification.

In analyzing the serious problems thus posed for the operation of REIT's one may raise two initial questions: does the Treasury Department have power to implement such a regulation and is such a regulation effective in furthering the statutory policy?

of basing the rent on incoine or profits, the income will not qualify as rent from real property. Treas. Reg. $\$ 1.856-4$ (b)(1) (1960).

28. The consequences of disqualification are discussed in text following note 8 supra.

29. Treas. Reg. $\S 1.856-2$ (c)(2)(ii) (1960). On the difficulty of applying this regulation, see text accompanying notes 42-77 infra.

30. See text accompanying note 1 supra. REIT's must also determine what constitutes "interest." For exainple, REIT's frequently use highly complex forms of real estate financing with mixed equity and debt participation. In a typical transaction the REIT might purchase the ground underlying an improved development and lease the fee back to the seller at a rate producing an effective yield to the trust that exceeds the maximum interest rate for loans. Depending upon various factors, including provision for mandatory repurchase, it is possible to construe this transaction as a hidden security device and hence a loan. See generally R. BERNHARDT, J. HETiand \& J. HIII, California Real Estate Secured Transactions 27-51 (1970).

A more difficult transaction to characterize is a purchase of land by an REIT with a leaseback to the seller, the trust providing the seller with long-term development financing at a lawful rate of interest. If the rent and interest taken together produce an overall yield that exceeds the lawful interest rate, it is important whether the transaction will be characterized as a loan.

Problems also arise in determining the meaning of "usury" or "rate of interest." For example, if the REIT purchases a participation (an interest in a loan previously negotiated by another lender, such as a bank) from a lender who is exempt by statute from the usury laws, it is unclear whether the trust may take shelter under the original lender's exemptiou or whether the interest received by the trust will be judged independently. Also, if the market rate of interest is higher than the rate borne by the note participated in, the original lender will bave to discount the note in order to sell it. If that discount provides an effective yield to the trust that is higher than the usury ceiling, will the income be disqualified? Such interest should not be disqualified if the rate the borrower must pay is not usurious, but the Treasury has issued no guidelines on this question. 
II

\section{JUSTIFICATION FOR AND EFFICACY OF THE REGULATION}

Although the regulation lacks a statutory basis, ${ }^{31}$ case law has established the authority of the Treasury Department and the Internal Revenue Service to respond to public policy considerations in administering the tax laws. ${ }^{32}$ Under this authority the IRS has disallowed, although not always successfully, ${ }^{33}$ taxpayer deductions or exemptions where allowance would have frustrated state or federal policy. ${ }^{34}$ The Supreme Court's position is that federal tax laws slould neither encourage violations of state law nor in any way mitigate state sanctions for illegal activity. ${ }^{35}$ Thus, withdrawal of the tax benefit normally available to the taxpayer is appropriate under such circumstances.

Evidently, concern that the tax laws not mitigate the state sanction for usury motivated the Treasury to disallow the inclusion of usurious or illegal interest in computing an REIT's qualified income. However, given that the Treasury is empowered to adopt such a regulation and even that the goal is laudable, it remains whether the regulation actually accomplishes the intended result.

In fact, the regulation fails to prevent use of the tax laws to mitigate or avoid state sanctions against usury. The primary tax benefit conferred upon REIT's is that they may pass income through to their shareholders without tax at the trust level. Except in a rather

31. See note 1 supra.

32. In Cammarano v. United States, 358 U.S. 498 (1959), the Supreme Court upheld Treasury Regulation 111, $\$ 29.23$ (1953), which prohibited taxpayers from deducting campaign or lobbying expenses as ordimary and necessary business expenses. The Court reasoned that the Treasury Department was responding to a valid public policy evidenced by the repeated enactment by Congrcss of former code section 23 (now section 162) dealing with deductions for business expenses. On the deductibility of illegally incurred expenses, see notes 32-35 supra and accompanying text.

33. See Commissioner v. Sullivan, 356 U.S. 27 (1958), where the Supreme Court permitted deduction by an illegal gambling establishment of rent and wages paid in connection with its gambhing activities. The Court reasoned that to do otherwise would make the business taxable on gross receipts rather than net income, and that if this decision were to be made, it should be made by Congress. Id. at 29 .

34. The leading case in this area is Tank Truck Rentals v. Cominissioner, 356 U.S. 30 (1958), where the Supreme Court held that fines imposed for violations of the state weight limits for trucks could not be deducted as ordinary and necessary business expenses under code section 162. The Court said that the test for deductibility was whether the tax benefit would "severely and immediately frustrate a sharply defined state policy." Id. at 34, quoting Commissioner v. Hemiger, 320 U.S. 467, 474 (1943).

35. The deliberate nature of the plaintiff's violation was not controlling in Tank Truck. In a companion case the Court held that deducting fincs resulting from an unintentional violation of state law would equally frustrate state policy. Hoover Motor Express Co. v, United Sțates, 356 Ụ.S. 38, 40 (1958), 
narrow situation, however, the regulation does nothing to withdraw this benefit from REIT's that charge usurious interest. Charging usurious interest does not disqualify an REIT per se, because only 90 percent of its income need be qualified. Thus, so long as it is otherwise qualified, an REIT that charges usurious interest may distribute that interest to its shareholders free of tax at the trust level.

For example, a mortgage trust ${ }^{36}$ may commit 10 million dollars to loans at $101 / 2$ percent interest; if the legal rate were 10 percent, the trust would have one million dollars qualified interest income and 50 thousand dollars unqualified usurious incoine. It would thereby meet the 90 percent test, and, if all other statutory provisions are met, all of the income, including the usurious portion, would pass through to the shareholders tax free. Such a violation of state usury laws would be unaffected by the regulation.

On the other hand, consider an equity trus ${ }^{37}$ that utilizes the sale and leaseback form for many of its acquisitions. Suppose that through the receipt of lawful, but unqualified, sources of income, such as commitment fees ${ }^{38}$ and the partial allocation of rents to furniture, ${ }^{39}$ approximately nine percent of its gross income is unqualified. A subsequent determination that one sale-and-lease back was in reality a loan ${ }^{40}$ could, if its resultant interest rate is usurious, push the trust's unqualified income over the limit of 10 percent, thus subjecting its entire income to tax at the trust level.

A more effective and equitable method of preventing trusts that charge usurious interest from reaping a benefit through the tax laws would deny the tax-free pass-through of usurious income and omit

36. There are two types of REIT's: those that emphasize lending, known as mortgage trusts, and those that invest in properties, known as equity trusts. The most successful mortgage trusts have been those that have written interim loans for construction projects where high yields are available; the life of the loan is usually short, which allows the trust to adjust to interest rate fluctuation. Equity trusts purchase income producing properties, such as apartment complexes and shopping centers, and derive their income from rents. Both forms inake extensive use of leveraging, that is, borrowing money at low rates by issuing commercial paper or obtainmg bank credit lines and financing projects with that money at higher rates. This added capital enables the trust to grow at a faster rate than would otherwise be possible, since the trust must distribute 90 percent of its earnings to the shareholders. See genterally FoRTUNe, Aug. 1970, at 173-75.

37. Equity trusts are described in note 36 supra.

38. Rev. Rul. 70-362, 1970 INT. Rev. BuLI. No. 28, at 23. A commitment fee is paid to a lender in order to ensure that a loan will be forthcoming; it is usually necessary in order to get commitments from subcontractors to do the work and is often a condition to the construction loan. A commitment to purchase and lease back may also be required as a condition to a construction loan.

39. Treas. Reg. \& 1.856-4(a) (1960).

40. On the uncertainty of the law of sales and leasebacks, see note 30 supra. 
such income from the income test entirely. In other words, to the extent an REIT receives interest in excess of the lawful rate, it would be taxed at both the trust and shareholder levels. Furthermore, to strengthen the sanction, it could be presumed that all the usurious income was distributed, even if the trust passed less than 100 percent of its income through to its beneficiaries. By withdrawing the tax benefit of a tax-free pass-through of income from usurious interest, the Treasury would be properly exercising its power as described by the Supreme Court. ${ }^{41}$ Nevertheless, although this revision overcomes the mequities of the current approach and apportions the penalty with the wrong sought to be prevented, it does not solve the enforcement problems created by conflicting state usury laws.

\section{III}

\section{Choice of LaW Problems}

Implementation of the regulation requires the IRS to deal with conflicting state usury laws. Because REIT transactions are often complex and involve property in several states, ${ }^{42}$ the IRS will have to decide which state's usury law applies in determining whetler usurious interest is being charged. There are two distinct methods that the IRS can use in making its decision: On the one hand, it can make its own analysis and determine the applicable law on clooice of law principles. Or, it can decline to apply the regulation unless there has been a court adjudication of the contract's validity in the particular case. That is, let litigation between the parties determine the applicable law and answer the internal law issues. This part argues that the IRS cannot rationally enforce its regulation by the first method and that the second method is not only better suited for implementing the policies involved but also has been used by the IRS when faced with a similar problesn in another context.

\section{A. Method One: Choice of Law Analysis}

There are at least two approaches that the IRS could take under the choice of law method. First, it could select the applicable law in every transaction by a fixed rule, always using, for example, the law of the borrower's domicile. On the other hand, it could choose to follow general choice of law rules such as the rule of validation as set forth in the Second Restatement or the interest analysis formulated by Brainerd Currie and refined by the California supreme court.

41. See note 35 supra and accompanying text.

42. For an example of the complexity of REIT transactions, see note 30 supra. 


\section{Fixed-State Rule}

Under the fixed-state approach, the IRS always applies the usury law of the state that has a specified contact with the transaction. For example, it could determine that the interest rate must be valid in the lender's domicile, the borrower's domicile, the place of negotiation, the situs of the property secured by the loan, or the law that the parties stipulate is to apply. This method has the advantage of facilitating planning by providing certainty of application in most cases, ${ }^{43}$ but it has a number of difficulties. If the IRS chose always to enforce the law of the lender, REIT's would be encouraged to locate in states with high interest maximums ${ }^{44}$ in order to lend throughout the country witlout risking disqualification. If, on the other hand, the IRS chose always to enforce the law of the borrower's domicile, the parties' autonomy would be severely restricted. ${ }^{45}$ There is little virtue in denying sophisticated parties ${ }^{46}$ the opportunity to make valid contracts by means of such common practices as contract stipulation, manipulation of places of negotiation, and so forth. In addition, choice of the borrower's domicile would make it difficult or impossible for borrowers in the low-interest-maximuin states to borrow from REIT's in a tight money market. ${ }^{47}$

Allowing the parties to stipulate the law governing their contract

43. If a domicile rule is chosen, it would not provide certainty in cases involving parties with dual domiciles, such as a corporation whose domicile is both the state of its incorporation and the state of its principal place of business. If the place of negotiation is chosen, the rule would not provide certainty in cases where the negotiations took place over an extended period of time in more than one statc.

44. Rhode Island, for example, has a inaximum interest rate of 21 percent. R.I. GEN. STAT. tit. 6, ch. 26, § 2 (1970). Indiaua, on the other hand, has a maximum rate of 6 percent. IND. GEN. STAT. tit. 19, ch. 12, 104 (1964). Many states do not permit corporations to raise the defense of usury under certain circumstances. See, e.g., AlA. GeN. Stat. tit. 9, § 67(2) (Supp. 1969); Del. Gen. Laws tit. 6, $\S 2306$ (1953); N.Y. GeN. Obligations Laws § 5-521 (McKinney 1971).

45. Of course, restriction of autonomy would also be a problem if the lender's domicile were chosen always to govern the contract. However, as the text indicates, REIT's would undoubtedly respond by locating themselves in states with high maximums.

46. REIT's generally make loans to developers of shopping centers, office buildings, and similar enterprises, rather than to individual homeowners. See Kearns, An Appraisal of the Real Estate Investment Trust Industry, Blythe \& Co. Research Report No. 240, Feb. 24, 1971, at 5.

47. For example, construction loans averaged 13 percent in 1969. See Kearns, supra note 46 , at 5 . In many states, the only lenders permitted to make such loans are banks and other licensed lending institutions exempt from usury laws. In New York, for example, a banking board sets the legal rate based on prevailing interest rates. N.Y. BaNkING Laws $\$ 14 a$ (McKinney 1970). In California the constitution exempts banks and building and loan associations from the usury laws. CAI. CoNst. art. 20, $\S 22$. 
would be equally unsatisfactory. ${ }^{48}$ By this approach, the IRS would virtually eviscerate its own regulation, since the parties will always stipulate a state's law that validates the contract. In fact, any state rule would often frustrate the policy of the regulation to assure that tax advantages are not given to taxpayers who violate state usury laws. ${ }^{49}$ An arbitrary designation of applicable state law could result in the enforcement of a law no state involved in the transaction would apply. For example, a court in the borrower's domicile might defer to the law of the lender's domicile if the forum state's interest is not strong enough to validate the contract..$^{50}$ If the IRS were to designate the law of the borrower as the applicable law for purposes of the regulation it would be denying qualification to trust income that would not be considered usurious by that state. The converse is also possible: a loan that might be considered usurious by state courts would not be considered usurious by the IRS because it is not usurious under the law of the designated state.

\section{General Choice of Law Rules}

By using general choice of law rules to determine the applicable state law, the IRS would avoid the inflexibility of the fixed-state method and more nearly accommodate true state policy. However, this method is not easy for the IRS to apply, and it makes planning difficult for REIT's. Because there is no single approach to choice of law embraced by all jurisdictions, ${ }^{51}$ the IRS would have to choose an approach from among competing theories. Moreover, even after making its choice, the IRS would have to balance the interests or factors that the chosen theory requires to be weighed, a difficult task both for the IRS

48. Restatement (Second) of Conflict of Laws $\$ 332 a$ (Tent. Draft No. 6, 1960) provides that the law stipulated by the parties shall apply. However, this provision is limited to situations not involving mistake, improper means, violation of public policy, or unreasonable basis for choice.

49. See text accompanying notes 34-35 supra.

50. See Ury v. Jeweler's Acceptance Corp., 227 Cal. App. $2 d$ 11, 38 Cal. Rptr. 376 (1st Dist. 1964). In this case a California court refused to apply California usury law to a transaction between a California borrower and a New York lender. Among the reasons given for the decision was "that California does not have such a strong public policy against any and all contracts which would be usurious if they were made and to be performed here ...."Id. at 20,38 Cal. Rptr. at 382. See also the discussion of the interest analysis and other approaches to conflicts of law in text accompanying notes $52-72$ infra.

51. For example, see the discussion of interest analysis and the rule of validation at notes 52-72 infra and accompanying text. See also Comment, Usury in the Conflict of Laws, 55 CaLIF. L. REv. 123, 141-81 (1967), which points out that in many cases a court purports to base its decision on a particular theory but actually looks to the equities of the situation. Of course, it would usually not be possible for the IRS to judge the equities of a situation since the parties to the transaction would be nonadversary. 
and for REIT's attempting to comply with the regulation. This portion of the Comment focuses on two approaches to choice of law-the rule of validation and interest analysis-to illustrate how the results vary depending upon the approach followed and how it is difficult to make conflict of law choices in the absence of an adversary forum.

a. Rule of validation. Courts and commentators have often assumed that a special rule, a modified version of the express rule of validation, applies to a conflict between state usury laws. ${ }^{52}$ This rule, as set forth in the Second Restatement, provides:

The validity of a contract will be sustained against the charge of usury if it provides for a rate of interest that is permitted by the general usury law of any state with which the contract has a substantial relationship and is not greatly in excess of the rate permitted by the state whose local law governs the validity of the contract . . . .53

The Second Restatement defines "substantial relationship" as a "normal and natural connection with the contract," which is indicated by the presence of certain contacts. ${ }^{54}$ The significant contacts are the state where the contract was made, the state in which the contract was to be performed, the situs of land given as security for the loan, the place where the loan was negotiated, and the domicile or place of business of the lender or borrower. The Reporter indicates that a single contact will not give a state the required relationship with the con-

52. Fahs v. Martin, 224 F.2d 387, 397-98 (5th Cir. 1955). See Kinney Loan \& Fin. Co. v. Sumner, 159 Neb. 57, 65 N.W.2d 240 (1954); Hawkins v. Ringel, 231 N.Y.S.2d 476 (Sup. Ct. 1962), rev'd mem., 19 App. Div. 649, 242 N.Y.S.2d 616 (1963). Restatement (SeCOND) of Conflict of Laws $\$ 334 d$, at 54-55, 62 (Tent. Draft No. 6, 1960).

53. Restatement (Second) of Conflict of Laws $\$ 334 d$ (Tent. Draft No. 6,1960 ). The express rule of validation is a description of the judicial practice of fulfilling the expectations of parties to a contract by applying the law that validates the contract. A. Ehrenzweig, Conflicts IN A Nutshell $\$$ 52, at 54-56 (1965). Many courts have expressly validated contracts that violate the applicable usury laws in the absence of compelling extenuating circumstances. Id. See also Comment, supra note 51, at 148. The first expression of this rule as applied to usury laws vas made by the Supreme Court in Seeman v. Philadelphia Warehouse Co., 274 U.S. 403 (1927). In that case the Court affirmed a judgment against the borrower, holding that parties may lawfully contract for a rate of interest higher than that permitted by the state where the contract was made, as long as the rate is lawful in a state having a "normal relation" to the contract. Id. at 410. However, the Court also pointed out that this rule would not apply if there were evidence of evasion of one of the state's usury laws. Id. at 408. This is essentially the rule of validation test. See notes 54-56 infra and accompanying text. Nevertheless, any IRS determination that there has been an atteinpt to evade the law of another state will be difficult without a cooperative borrower. For a general discussion of Seeman and its doubtful historical basis, see Comment, supra note 51, at 165-66.

54. RESTATEMENT (SECOND) OF CONFlict of LAws, $\S 334 \mathrm{~d}$, at 56 (Tent. Draft No. 6, 1960). 
tract; ${ }^{55}$ rather, the determination requires a delicate balancing process. ${ }^{56}$

Furthermore, if the IRS chooses to apply the rule of validation, it will have to make in each case a second determination requiring the balancing of contacts: it must determine which state's law would normally govern the contract. If that state is not one liaving a substantial interest and permitting the rate of interest specified in the contract, the IRS must judge whether the rate charged is "greatly" in excess of the rate permitted by that state. ${ }^{57}$ The two-percentage-point difference between a 12 percent rate that it would be permissible to cliarge a borrower on real estate in Michigan ${ }^{58}$ and the 10 percent limit imposed by California ${ }^{59}$ may not be greatly excessive, but it is twice as great as the maximum rate permitted in Arkansas. ${ }^{\circ 0}$ Presumably, the position of any line drawn will have to shift with changes in such factors as the tightness of the money market; therefore, clear IRS guidelines will be necessary if REIT's are to predict what will be permissible.

Finally, the IRS must take into account the exceptions that courts sometimes make when the interest rate charged is higher than that permitted by the borrower's domicile. The exception arises when validation would violate a strong public policy of the borrower's state ${ }^{61}$ or

55. Id. The Restatement does assert that two or three significant contacts are likely to give a state a substantial relationship with the contract. Id. $\S 334$, at 54 .

56. The Reporter also indicates that the place where the contract was made and the place where it is to be performed are both easily manipulated and therefore "suspect." Id. Similarly, the Restatement provides for "contacts of lesser importance" such as where the contract was dated, where the money is to be used, and where a corporate borrower or lender is incorporated. Id. at 57. A preponderance of these "suspect" or "lesser" contacts must be buttressed by the presence of one or two "significant" contacts for a substantial relationship to emerge. Id. at 56,61 . On the other hand, since the presence of only one significant contact is insufficient to creato the required relationship, the presence of lesser or suspect contacts may or may not swing the balance in favor of validation. Id. at 57.

57. See note 53 supra and accompanying text.

58. Michigan's usury law prohibits borrowers from raising the defense when the loan secures real property. Mich. GEN. LAWs § 450.78 (1970).

59. The California constitution sets the maximum interest rate at 10 percent. CAL. CONST. art. XX. This limitation protects corporate as well as individual borrowers.

60. The maximum legal interest rate in Arkansas is 6 percent. ARr. Const, art. $19, \S 13$. There is no provision that corporate borrowers are denied the defense of usury. The rule of validation formulated by the Second Restatement was based on the notion that since the differences between state maximum interest rates were generally small, the parties' expectations should be upheld in most cases. RESTATEMENT (SECOND) OF CONFLICT OF LAWS \& 334d, Comments $a-b$, at 54-55. Therefore, a two-percentage-point difference would probably be within the limit intended by the rule. However, wider spreads will probably occur when money is tight; and, in any event, a difforence of a factor of two, as in this example, does sound excessive and is not difficult to find.

61. See Hutchingson v. Republic Fin. Co., 236 Ark. 832, 836, 370 S.W.2d 185, 
when there appears to have been an attempt by an unscrupulous lender to evade the borrower's law by manipulating the place of negotiation, execution, or performance of the contract. ${ }^{62}$ Although the Second Restatement provides for these exceptions to some extent, ${ }^{63}$ validation is not precluded by a finding of evasion or manipulation; rather, validation under such circumstances requires the presence of other contacts such as domicile, principal place of business, or situs of negotiations. b. Interest analysis. Another way the IRS could solve the conflicts problem inherent in Treasury Regulation section 1.856(c)(2)(ii) is to use the interest-analysis approach, ${ }^{64}$ which, in the case of a court, involves an initial examination of forum law to determine the extent of the forum's interest in the case. If the forum state has an interest and the foreign state has none, the court should apply its own law regardless of the quality and quantity of contacts with other states. ${ }^{65}$ If the

187 (1963) (strong public policy against usury evidenced by heavy penalties). For a general discussion of the decisions stressing public policy considerations, see Comment, supra note 51 , at $172-75$.

62. See Clarkson v. Finance Co. of America, 328 F.2d 404 (4th Cir. 1964); Lyles v. Union Planters Nat'I Bank, 393 S.W.2d 867 (Ark. 1965); Atlas Subsidiaries, Inc. v. O. \& O. Inc., 166 So. 2d 458 (Fla. App. 1964). For a discussion of manipulation see Ringer v. Virgin Timber Co., 213 F. 1001 (E.D. Ark. 1914).

63. See note 53 supra and accompanying text.

64. See generally B. Currie, Married Women's Contracts, 25 U. CH. L. Rev. 227 (1958); B. Currie, Notes on Methods and Objectives in the Conflict of Laws, Duke L.J. 171 (1959). See also D. Cavers, The Chorce of Law Process (1965). For a critique of the governmental-interest approach, see Ehrenzweig, Foreign Guest Statutes and Forum Accidents, 68 ColvM. L. REv. 49 (1968). The rule of validation and the Second Restatement, on the other hand, are representative of a conflicts approach that emphasizes the avoidance of forum shopping. To proponents of this approach, the ideal toward which courts should strive is identical resolution of the dispute regardless of forum. See "Judge Griswold's" opinion in An Imaginary Case, in D. Cavers, The Chorce-of-Law Process 19-32 (1965).

65. Cf. Emery v. Emery, 45 Cal. 2d 421, 289 P.2d 218 (1955); Grant v. McAulliffe, 41 Cal. 2d 859, 264 P.2d 944 (1953). One of the advantages of this approach is that it avoids the false conflict situation, which arises when a court applies its own law even though it has no interest in the outcome of the case or, conversely, applies foreign law even though the forun is the only interested state. For example, when a borrower and a lender are from the same state, a foreign forum has no interest in applying its own usury law, since the forum usury law was presumably designed to protect forum borrowers. Under the Second Restatement, however, forum law might apply if the foreign state lacked the required contacts with the contract. This could occur if other "significant contacts" were with the forum state. See text accompanying notes 54-56 supra.

Another advantage of this theory is that it can solve true conflicts predictably. Thus, where both the forum and the foreign state have equal interests in the outcome of the case, there is an irreconcilable conflict. Strict interest-analysis theory would apply the forum law as an alternative to tossing a coin. In fact, however, Professor B. Currie, as well as interest-analysis courts, have not taken this position; rather, they have balanced the interests of the states to determine which is the more compelling, and they have never found the interests to be exactly equal. See B. Currie, The Disinterested Third State, 28 LAW \& CONTEMP. ProB. 754, 757 (1963). See also the 
forum has no interest in the outcome, but the foreign state does, it applies foreign law. If both states have an interest, the forum state balances the two to determine which should prevail. ${ }^{60}$

The difficulty with this theory as applied to the regulation is that there is no forum when the IRS makes its determination. This should not be a problem when the interest rate in question is not usurious in the state of the borrower's domicile, since the loan would always be valid; only the borrower's domicile has a protective interest. However, if the interest rate is usurious in the borrower's domicile, the absence of a forum could be troublesome. In the first place, the IRS will have enough difficulty in balancing one state's interest in protecting the borrower agamst the other state's interest in upholding commercial transactions. In Ury v. Jeweler's Acceptance Corp. ${ }^{67}$ for example, a California court held that California's public policy against usurious interest did not override New York's interest in securing commercial transactions, ${ }^{68}$ as evidenced by the imapplicability of its usury laws to corporate borrowers. It therefore appled New York law even though the borrower was a California resident. The court emphasized, however, that it would apply California law if it had found the interest rate unconscionable. ${ }^{69}$ Different states may strike the balance in different ways, and even if a revenue agent investigating a multistate transaction assumes that any legal action would most likely be brought in the state of the borrower's domicile, he has no way of knowing how a court in that state would evaluate the strength of the state policy under the particular circumstances. The absence of a forum compounds this problem because the IRS must ehicit facts from nonadversary parties in order to determine the strength of the policy. ${ }^{70}$

discussion of Reich v. Purcell, 67 Cal. 2d 551, 432 P.2d 727, 63 Cal. Rptr. 31 (1967), in text accompanying note 71 infra.

66. Reich v. Purcell, 67 Cal. 2d 551, 432 P.2d 727, 63 Cal. Rptr. 31 (1967).

67. 227 Cal. App. 2d 11, 38 Cal. Rptr. 376 (1st Dist. 1964). California is an interest-analysis jurisdiction. In Bernkraut v. Fowler, 55 Cal. 2d 588, 360 P.2d 906, 12 Cal. Rptr. 266 (1961), the California supreine court utilized interest analysis to find that the California statute of frauds did not apply to an oral contract made in Nevada by residents of Nevada. The court held that even if the defendant had been a California resident, California's interest in applying its statute of frauds did not extend to cases where the parties to the contract could not reasonably expect California law to apply. Rather, the policy was aimed primarily at local transactions. Id. at 594, 360 P.2d at 909, 12 Cal. Rptr. at 269. See also Reich v. Purcell, 67 Cal. 2d 551, 432 P.2d 727, 63 Cal. Rptr. 31 (1967). Professor Currie approved of this use of interest analysis. He felt courts should exannine the policy of the forum in relation to the circumstances of each case in order to avoid applying a law under circumstances where it was not meant to apply. B. Currie, The Disinterested Third State, 28 LAW \& CoNtemp. Prob. 754, 757 (1963).

68. 227 Cal. App. $2 d$ at 20, 38 Cal. Rptr. at 382.

69. Id.

70. The borrower has no interest in helping the IRS disqualify his lender from REIT status unless he is engaged in litigation with him over the usury question. 
Furthermore, the absence of a forum compels the Service to balance the interests from the point of view of a number of different states. In addition to the domicile of the borrower and the lender, the state where the real property security is located is a possible "forum." For example, the lender could foreclose there, whereupon the borrower might assert the defense of usury. Since its citizens would not be involved, that state court might react like the California supreme court in Reich $v$. Purcell, ${ }^{71}$ which characterized itself as a disinterested third forum and balanced the different interests of the plaintiff's state and the state of the place of injury. ${ }^{72}$ Therefore, if the IRS should adopt an interest-analysis approach, it would have to analyze and balance interests from the point of view of the borrower's state, the lender's state, and possibly a disinterested third forum.

\section{B. Method Two: Court Adjudication Rule}

The problem with using state choice of law rules to determine the applicable law for implementation of the regulation is that the IRS would have to make decisions for which it is not equipped. Whether it bases its decision on the interests or the contacts involved, it will frequently have to weigh the relative strength of public policies and probe the motivations of the parties involved. Furthermore, in order to do either, the IRS will have to solicit information from nonadversary parties.

A more sensible approach is to apply the regulation to multistate transactions only where there has been a state court decision that the interest charged in a particular case is usurious. This approach has two advantages: First, it eliminates the danger that the IRS would make a wrong decision. For example, the IRS would not have to speculate on the strength of a particular state policy either in determining whether an exception exists to the rule of validation or in evaluating the interests of the relevant states. Second, it more nearly approximates actual state policy. Since usury laws were not designed to prevent a sophisticated borrower from making a contract on terms it finds acceptable in an arms-length transaction, a court adjudication

71. 67 Cal. 2d 551, 432 P.2d 727, 63 Cal. Rptr. 31 (1967). This case involved an automobile accident between a California defendant and Ohio plaintiffs. The accident took place in Missouri, which had a $\$ 25,000$ limit on recovery for wrongful death. Ohio and California had no limit on rccovery. The California supreme court held that California had no interest in the case because the accident took place in Missouri and the California wrongful death statute was designed to protect California residents in California. As a disinterested third forum, the court held that Ohio law applied since the Missouri statute was designed to limit liability only for its own residents. Id. at 556, 432 P.2d at 730, 63 Cal. Rptr. at 34-35.

72. Id. at 556, 432 P.2d at 730, 63 Cal. Rptr. at 34-35. 
rule would apply the law only when it was designed to apply-when there is a genuine dispute over the validity of the interest rate charged. ${ }^{73}$

The IRS used a similar approach in deciding the validity of divorce decrees. In a series of rulings beginning with G.C.M. 25250, ${ }^{74}$ the IRS established a policy of validating divorce decrees as long as there is no invalidating court decision. ${ }^{75}$ Where a court of coinpetent jurisdiction declares a divorce to be invalid, however, that decision prevails over the divorce decree. ${ }^{76}$

This policy indicates the willingness of the IRS to avoid the difficulties of determining the validity of a person's marital status without the resources available to a court. The IRS takes this position despite a tax advantage to the taxpayer who is able to deduct alimony payments while perhaps still legally married. This is reasonable, however, since it is unlikely that a married couple would attempt to use the alimony provisions in this way. ${ }^{77}$ Similarly, it is unlikely than an REIT transaction will involve a weak and necessitous borrower, so there is little risk that, absent a court adjudication, a tax advantage ${ }^{78}$ would accrue to a lender making an unconscionable loan.

\section{IV}

\section{A Proposal for Change}

In order to avoid the implementation and enforcement problems raised by conflicting state usury laws, a new regulation should be promulgated that applies only to transactions adjudicated to be usurious. In addition, as discussed in part II, any new regnlation should tax usurious interest at both the trust level and the shareholder level in order to

73. The usury laws are also designed to deter lenders generally from charging usurious rates of interest, and thus to protect weak borrowers who cannot sue. This policy is not applicable to the REIT situation either, however, since borrowers from REIT's are sophisticated developers.

74. 1947-2 CuM. BuLL. 32.

75. Rev. Rul. 67-442, 1967-2 CuM. Bull. 65; cf. G.C.M. 25250, 1947-2 CuM. BULL. 32.

76. Rev. Rul. 67-442, 1967-2 CuM. Bull. 65. In adopting this policy, the IRS rejected decisions in the Second and Third Circuits holding a divorce valid for tax purposes even if there is an invalidating court decision, as long as the divorce is valid in the granting jurisdiction. Estate of Borax v. Commissioner, 40 T.C. 1001 (1963), rev'd, 349 F.2d 666 (2d Cir. 1965), cert. denied, 383 U.S. 935 (1966); Feinberg v. Commissioner, 198 F.2d 260 (3d Cir. 1952). This conflict, however, does not bear on the Service's decision to validate uncontested divorce decrees.

77. Moreover, even if such an atteinpt were made, the IRS could always try to prove fraud.

78. The tax advantage is that usurious interest would count toward the total percentage of real property imcome necessary for a trust to qualify as an REIT and thus be taxed only at the shạręholdẹr levẹ. Sẹe text accompanying notes 17-29 supra. 
correlate its sanctions with the policy against usurious interest. Such a regulation might read as follows:

In the event it is determined by a state or federal court that a transaction is properly characterized as a usurious loan, the usurious interest derived from that loan will be excluded from the income test of section 856 (c) (2)-(4) and will be taxed to the Real Estate Investment Trust as though the Trust were a corporation. The tax will be computed as though 100 percent of the Trust's income were distributed to the beneficial owners of the Trust.

By refraining from invoking the regulation until a state court has ruled on the transaction, the IRS avoids two problems: First, the Service does not interfere with the sophisticated borrower's autonomy of contract. Interest will be disqualified only when a borrower has persuaded a court that his transaction is usurious under the applicable state law. Second, the IRS inquires neither into the facts nor the state laws that govern those facts. This is desirable because in many cases such an inquiry would be fruitless due to the complexity of the issues and the nonadversary positions of the borrower and lender. Most importantly, the proposed regulation advances the policies involved: state law is not frustrated, ${ }^{79}$ and the punitive effect of the regulation is felt by the REIT in direct proportion to its culpability.

Auban Ann Eisenhrardt

79. The suggestion by NAREIF [see note 1 supra and accompanying text] that the entire regulation be withdrawn would not advance this policy. If the regulation were withdrawn, the REIT would still be able to gain a tax benefit on income from usurious interest; the interest would be included under the income test of section 856(c) (2)-(4) and would be passed through tax-free to the shareholders. Under the regulation proposed in the text, usurious income would be excluded from both gross income and qualified incoine and would be taxed separately at the corporate rate. 